\title{
Morphological and molecular identification of Cryptocotyle lingua metacercariae isolated from Atlantic cod (Gadus morhua) from Danish seas and whiting (Merlangius merlangus) from the English Channel
}

\author{
Maureen Duflot ${ }^{1,2} \mathbb{D} \cdot$ Mélanie Gay $^{1} \mathbb{D} \cdot$ Graziella Midelet $^{1}(\mathbb{D}) \cdot$ Per Walter Kania $^{3} \mathbb{D} \cdot$ Kurt Buchmann $^{3} \mathbb{D}$
}

Received: 31 May 2021 / Accepted: 2 August 2021 / Published online: 27 August 2021

(c) The Author(s) 2021

\begin{abstract}
Trematode larvae (metacercariae) causing black spot disease occur frequently in gills, fins, skin and the superficial muscle layers of marine fish. Species within the genus Cryptocotyle Lühe, 1899 are frequently associated with this disease. Descriptions of the metacercarial stage are relatively limited and none has hitherto been reported from fish from the English Channel. The present study reports the morphological and molecular identifications of encysted black spot-inducing parasites from whiting (Merlangius merlangus) and Atlantic cod (Gadus morhua) caught respectively from the north coast of France (English Channel) and from Danish sea waters. Metacercariae were characterised morphologically based on microscopic observations and molecularly using Sanger sequencing of fragments of the mitochondrial coxl gene and rDNA ITS region. Morphological data were compared with available data in the literature. Phylogenetic trees including reference sequences were built to confirm morphological and molecular identifications. This survey constitutes the first description of $C$. lingua metacercariae in the English Channel ecosystems.
\end{abstract}

Keywords Cryptocotyle $\cdot$ Morphological identification · Molecular identification · Heterophyidae $\cdot$ English Channel · Whiting

\section{Introduction}

Marine fish are sometimes speckled with "black spots" induced by a host response to a trematode infection (Aalvik et al. 2015; Borges et al. 2015; Kristoffersen 1991; Sindermann \& Farrin 1962). Several genera cause these symptoms. Among them, the genus Cryptocotyle Lühe, 1899 (synonyms Tocotrema Looss, 1899 and Hallum Wigdor, 1918 from Rees (1974)) is a taxon of trematodes

Section Editor: Matthew Thomas Wayland.

Mélanie Gay

Melanie.Gay@anses.fr

1 Laboratory for Food Safety, ANSES, Boulogne-sur-Mer, France

2 University of Littoral Côte d'Opale, Boulogne-sur-Mer, France

3 Laboratory of Aquatic Pathobiology, Department of Veterinary and Animal Sciences, Faculty of Health and Medical Sciences, University of Copenhagen, Frederiksberg C, Denmark belonging to the family Heterophyidae. According to the World Register of Marine Species (www.marinespecies.org), this genus includes 12 species, but only 6 of them circulate among inhabitants of marine and brackish waters. Most species have only a partial description of their host spectra. Cryptocotyle badamshini Kurochkin, 1959 was described only in marine waters and was first described in Pusa caspica from the Baltic Sea. Cryptocotyle concava Creplin 1825 was observed in freshwater snails, from the genus Hydrobia, and freshwater or brackish fish such as sticklebacks or gobies and has, as definitive hosts, birds such as gulls or ducks as well as cats (Gonchar 2020; Thieltges et al. 2008; Zander et al. 1984). Cryptocotyle cryptocotyloides Issaitschikow 1923 was first described as an avian parasite (Witenberg 1929). Cryptocotyle delamurei Jurachno 1987 was first described in the northern fur seal. Cryptocotyle lingua Creplin 1825 has Littorina littorea as the first intermediate host (Blakeslee et al. 2008; Landis et al. 2012), a variety of marine fish as second intermediate host such as gobies, gadoids, clupeids (Borges et al. 2015; Duflot, et al. 2021a; Goncharov et al. 2017) and piscivorous birds as final host (Linton 1915; Stunkard 1942). The first intermediate host of Cryptocotyle 
jejuna Nicoll, 1907 is Hydrobia ulvae, several species of gobies were described as second intermediate hosts and piscivorous birds as definitive host (Goncharov et al. 2017).

Cryptocotyle is a heteroxenous parasite (Smyth 1994; Stunkard 1929). Adults are present in the intestines of marine birds. Eggs are passed in bird host faeces and ingested by the first intermediate host, an aquatic snail. Eggs hatch and go through one free larval stage, the miracidium, and three successive larval stages in the snail: the sporocyst, the redia and the cercaria. Cercariae are released from the snail and actively swim to the next host, a fish, penetrating its skin and infecting the skin and the subcutaneous muscle of the fish host. It then encysts and develops into the metacercarial stage. The fish immune system responds with humoral and cellular reactions (Buchmann et al. 2009). Melanophores concentrate at the infection site; melanisation is visible to the naked eye (Mazzi 2004). Metacercariae protect their soft tegument against this fish immune response by developing a proteinaceous cyst wall resistant to pepsin and acids (El-Mayas \& Kearn 2009). Birds belonging to the family Laridae, such as gulls, complete the Cryptocotyle life cycle by eating parasitised fish. Encysted metacercariae resist digestion by the bird's gastric juices and migrate to the proximal intestine where they excyst in alkaline conditions when exposed to chymotrypsin and trypsin. Subsequently, the juvenile parasites attach to the avian intestinal wall and develop into the adult stage (Buchmann et al. 2009).

Some studies have described the distribution of Cryptocotyle. To date, it has been observed in Europe, North America and Asia. Host species reported infected with Cryptocotyle include Littorina littorea snails from Western Scotland (McQueen et al. 1973) and the Baltic, North and Celtic seas (Europe) (Thieltges et al. 2009), North American fish, i.e. herrings (Clupea harengus) from the northern New England coast (USA) (Sindermann \& Farrin 1962) and cunners (Tautogolabrus adspersus) from the Newfoundland coast (Canada) (Sekhar 1970), as well as stray dogs from Rebun Island, Hokkaido (Japan) (Yoshimura 1965). Similarly, Cryptocotyle infections have been recorded in many North European marine fish species including Atlantic cod (Gadus morhua) (Borges et al. 2015; Koie 1984) and whiting (Merlangius merlangus) (Rea \& Irwin 1991).

To our knowledge, no studies on Cryptocotyle infections in fish from the English Channel have been performed. Moreover, morphological measurements are mainly available for the adult stage (Linton 1915; Ransom 1920) and descriptions of metacercariae stages are still scarce (Borges et al. 2015; Linton 1915; Rees 1978). Over the past 15 years, molecular identification tools have been developed for Cryptocotyle (Blakeslee et al. 2008; Borges et al. 2015; Casalins et al. 2020; Duflot et al. 2021b; Gonchar 2020; Tatonova \& Besprozvannykh 2019). In the present study, Cryptocotyle metacercariae sampled from naturally infected fish caught in the English Channel and the North Sea were morphologically described and molecularly characterised based on coxl gene and ITS region sequences.

\section{Materials and methods}

\section{Sample collection}

One batch of cod and one batch of whiting were fished and observed. Only parasitised fish were considered for the present study. Five parasitised Atlantic cod (G. morhua) individuals were caught by using net traps in Danish waters (Øresund) south of Helsingør, Denmark, in October 2019. Fish had a mean total length of $15.4(14-16.5) \mathrm{cm}$. Six parasitised whiting (M. merlangus) were caught off the French coast of the English Channel between October and November 2019. Fish had a mean total length of $17.2(15.7-17.9)$ $\mathrm{cm}$.

\section{Parasite detection}

To assess the level of infection, the location and number of black spots were observed and counted on each sample. Then, each fish was skinned and the subcutaneous muscle with a thickness of approximately $5 \mathrm{~mm}$ was removed from the fish. Skin and muscle samples were digested separately in a pepsin/ $\mathrm{HCl} /$ saline solution (Borges et al. 2015) in 50-mL beakers under magnetic stirring $(200 \mathrm{rpm}$, round magnet $\mathrm{L}=40 \mathrm{~mm}$ ) at $37^{\circ} \mathrm{C}$ for $1 \mathrm{~h}$. Digested samples were poured into Petri dishes. Metacercariae were collected by pipetting under an Olympus SZX16 stereomicroscope (Olympus Corporation, Tokyo, Japan). They were kept in phosphatebuffered saline (PBS) $(\mathrm{pH}=7.3)$ at room temperature.

\section{Excystment of metacercariae}

Metacercariae recovered from each sample were transferred to $30-1000 \mu \mathrm{L}$ of $2 \%$ porcine trypsin (13,000-20,000 BAEE units/mg, Sigma-Aldrich, USA) in PBS (pH 7.3) at room temperature for no more than $2 \mathrm{~h}$ whereby the cyst wall opened and live metacercariae emerged. Excysted metacercariae were stored in $96 \%$ ethanol at $1 \pm 1{ }^{\circ} \mathrm{C}$.

\section{Morphological identification}

Respectively, 5 and 10 excysted metacercariae from cod and whiting were analysed and identified under a light microscope (Leica DLMB 5000 B; Leica, Wetzlar, Germany). Excysted metacercariae stored in ethanol were rinsed in distilled water, stained with haematoxylin and mounted on slides in a glycerine gelatine medium (Buchmann 2007). The parasites and their main organs were measured (Table 1) 
( $\times 100-200$ magnification $)$ and photographed under a Leica DLMB microscope with a Leica DC300 camera. The parasites used for the measurements were uncompressed and parasites used for photos were flattened under a coverslip to bring as many morphological features into focus as possible.

\section{Molecular identification}

Three excysted metacercariae per fish preserved in $96 \%$ ethanol were air-dried and lysed at $55^{\circ} \mathrm{C}$ under orbital stirring at $300 \mathrm{rpm}$ in $30 \mu \mathrm{L}$ of lysis reagent (Borges et al. 2015) with a ThermoMixerC heater (Eppendorf, Hamburg, Germany). Complete lysis was confirmed by microscopy, whereafter proteinase $\mathrm{K}$ was inactivated by heating to $95^{\circ} \mathrm{C}$ for $10 \mathrm{~min}$ (Thuy et al. 2010).

PCR reactions were performed in a total volume of $60 \mu \mathrm{L}$ containing $2 \mu \mathrm{L}$ of extracted genomic DNA, 1 unit of HotStarTaq DNA polymerase (Qiagen, Hilden, Germany), 1X reaction buffer, $0.1 \mathrm{mM}$ dNTPs, $0.75 \mathrm{mM} \mathrm{MgCl}_{2}$ and $1 \mu \mathrm{M}$ each primer (Eurofins, Nantes, France). A partial region of the mitochondrial coxl gene (approximately $350 \mathrm{bp}$ ) was amplified using primers JB3 (5'-TTT TTT GGG CAT CCT GAG GTT TAT-3') and JB4.5 (5' -TAA AGA AAG AAC ATA ATG AAA ATG-3') (Borges et al. 2015; Bowles et al. 1993). PCRs were carried out under the following conditions: $94{ }^{\circ} \mathrm{C}$ for $15 \mathrm{~min}$ (initial denaturation step), followed by 40 cycles of $94{ }^{\circ} \mathrm{C}$ for $1 \mathrm{~min}$ (denaturation), $50{ }^{\circ} \mathrm{C}$ for $1 \mathrm{~min}$ (annealing), $72^{\circ} \mathrm{C}$ for $1 \mathrm{~min}$ (elongation) and a postelongation step at $72{ }^{\circ} \mathrm{C}$ for $7 \mathrm{~min}$, and then stored at $4{ }^{\circ} \mathrm{C}$. The complete nucleotide sequence of the ITS1-5.8S-ITS2 region of rDNA (approximately $1200 \mathrm{bp}$ ) was amplified using the primers BD1 (5'-GTC GTA ACA AGG TTT CCG TA-3') and 28S1R (5'-AAG TAT TTA GCC TTG GAT GGA GTT T-3') (Shumenko et al. 2017). PCRs were carried out under the following conditions: $94{ }^{\circ} \mathrm{C}$ for $15 \mathrm{~min}$ (initial denaturation step), followed by 35 cycles of $94{ }^{\circ} \mathrm{C}$ for $30 \mathrm{~s}$ (denaturation), $55^{\circ} \mathrm{C}$ for $30 \mathrm{~s}$ (annealing), $72{ }^{\circ} \mathrm{C}$ for $2 \mathrm{~min}$ (elongation) and a post-elongation step at $72{ }^{\circ} \mathrm{C}$ for $5 \mathrm{~min}$, and then stored at $4{ }^{\circ} \mathrm{C}$. All PCR reactions were run on a Thermal Cycler (Applied Biosystems, Forster City, CA, USA).

All PCR products were run on a $2 \%$ agarose gel and stained with ethidium bromide for visualisation. PCR products of the expected size were sequenced twice and from both sides (forward and reverse), using Sanger sequencing (Genoscreen, Lille, France) with the above-described primers.

\section{Sequence alignment and phylogenetic analysis}

Obtained sequences were visualised in BioEdit 7.0.9.0 software (Hall 1999); they were then assembled using MEGA 10.1.8 (Kumar et al. 2018). Ambiguous bases were clarified and called using the corresponding chromatograms. Nucleotide sequences were aligned using the Clustal W option of MEGA 10.1.8. A BLAST search was carried out for each DNA region (Altschul et al. 1997). Maximum Likelihood (ML), Neighbour Joining (NJ) and Minimum Evolution (ME) methods were conducted for separate and combined nucleotide data sets with other Heterophyidae sequences using MEGA 10.1.8. The trees were built with outgroups from the superfamily Opisthorchioidea (Table 2) and using 1000 bootstrap replications. Similar trees were observed, ML trees giving higher bootstrap values are shown. The most suitable fit model of each gene fragment was determined using the corrected Akaike Information Criterion (AICc) and the Bayesian Information Criterion (BIC) on the 24 models tested in MEGA 10.1.8. ITS and coxl sequences were respectively fitted to the $\mathrm{JC}(+\mathrm{I})$ model (Jukes \& Cantor 1969) and the Tamura-Nei model (Tamura \& Nei 1993). The highest log likelihoods were respectively (-3406.77) and (-7906.05).

\section{Results}

The intensity of infection varied between 120 and 173 black spots per fish for the five analysed cod samples (Fig. 1 a). The intensity varied between 10 and 349 black spots per fish for the six analysed whiting samples. Metacercariae were mainly localised on the fins, skin, subcutaneous muscles and especially in paraspinal connective tissues in both fish species (Fig. 1 b).

\section{Morphological identification}

Classical measurements were taken for 15 metacercariae (Table 1). Based on observations, the general morphology was drawn (Fig. 2).

\section{Description of metacercariae from whiting (based on 10 whole-mounted specimens)}

Excysted metacercariae linguiform to pyriform according to the state of contraction at fixation in ethanol (Fig. 3 a), length $0.60(0.44-0.92) \mathrm{mm}$, first width $0.23(0.11-0.31)$ $\mathrm{mm}$, maximum wide or second width at the posterior end of body $0.17(0.14-0.25) \mathrm{mm}$; anterior body covered by scale-like spines; oral sucker subterminal with a circular aperture, $0.05(0.03-0.06) \mathrm{mm}$ in diameter; prepharynx short and pharynx elliptical; oesophagus rectilinear; intestinal bifurcation occurs at one-fourth of body length; ventral sucker $0.03(0.02-0.05) \mathrm{mm}$ in diameter, on median line from one-half to two-thirds of the total length according to the condition of contraction; testes immature, in the posterior end of the body, detected close to the median 






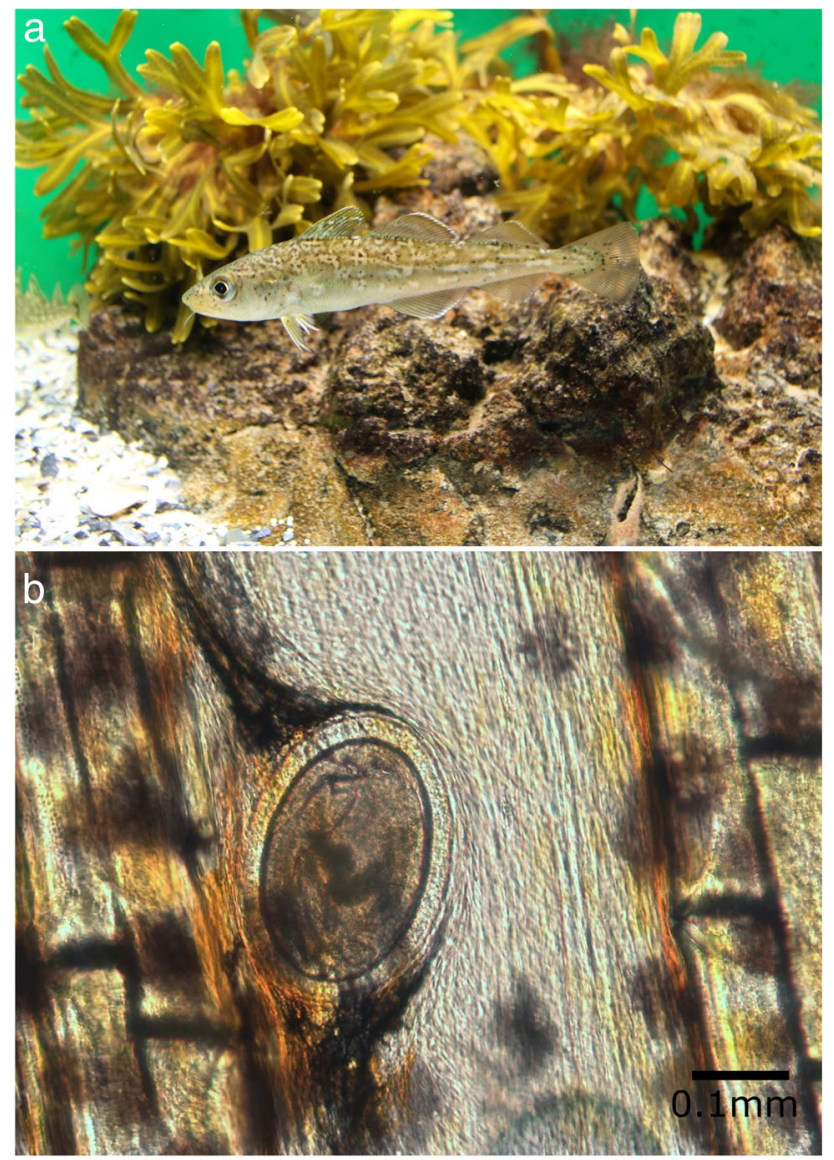

Fig. 1 Infected Atlantic cod (Gadus morhua) (a) and microscope observation of encysted metacercariae in caudal fin (b)

line; structures assumed to be seminal receptacles detected in some metacercariae, ovary just pre-testicular in the posterior end of the body.

\section{Description of metacercariae from cod (based on five whole-mounted specimens)}

Body shape linguiform to pyriform according to the state of contraction (Fig. 3 b), length $0.51(0.39-0.59) \mathrm{mm}$, maximum width in anterior end $0.23(0.20-0.26) \mathrm{mm}$ and a second width in posterior end $0.17(0.14-0.21) \mathrm{mm}$; tegument slightly spine anteriorly; oral sucker subterminal and round, 0.05 (0.05-0.06) $\mathrm{mm}$ in diameter; prepharynx short and pharynx elliptical; oesophagus straight; intestinal bifurcation occurs at one-fourth of body length; ventral sucker small, $0.02(0.02-0.03) \mathrm{mm}$ in diameter, on median line at one-half to two-thirds of the total length according to the condition of contraction; testes immature, in the posterior end of the body, detected close to the median line; structures assumed to be seminal receptacles detected in some metacercariae, ovary just pre-testicular in the posterior end of the body.



Fig. 2 Morphology of excysted Cryptocotyle lingua metacercariae (ventral view) from Gadus morhua and Merlangius merlangius. Abbreviations: bi.i, bifurcation of intestine; e, oesophagus; ex.c, excretory canal; ex.p, excretory pore; ic, intestinal caecum; pp, prepharynx; ph, pharynx; ov, ovary; os, oral sucker; s.r, seminal receptacle; t, testis; vg.c, ventrogenital complex; vi, vitellaria; (1) distance from oral sucker to end of pharynx; (2) distance from oral sucker to intestinal branches; (3) width 1; (4) width 2; (5) oral sucker diameter; (6) ventrogenital complex diameter; (7) total length

\section{Molecular identification and phylogenetic data}

PCR on the coxl gene of mtDNA was performed on 29 parasites: 15 isolates from infected whiting and 14 isolates from infected Atlantic cod. PCR products were about $320 \mathrm{bp}$ long. Likewise, PCR of the ITS region of rDNA from 28 parasites including 10 isolates from whiting and 18 isolates from cod resulted in a product of about $1700 \mathrm{bp}$. Sequences of the coxl gene and ITS region were deposited in GenBank under the accession numbers MW542531-MW542559 and MW544112-MW544139, respectively. BLAST analysis of the coxl fragments ( $281 \mathrm{bp}$ ) led to $100 \%$ of similarity with GenBank accession nos. KJ711861, KJ711862, KJ711865, KJ711866 (C. lingua, Baltic Sea, Denmark) and EU876519 (C. lingua, Canada) for 24 sequences. Four sequences had 99.69\% similarity with the KJ711866 sequence, each at 

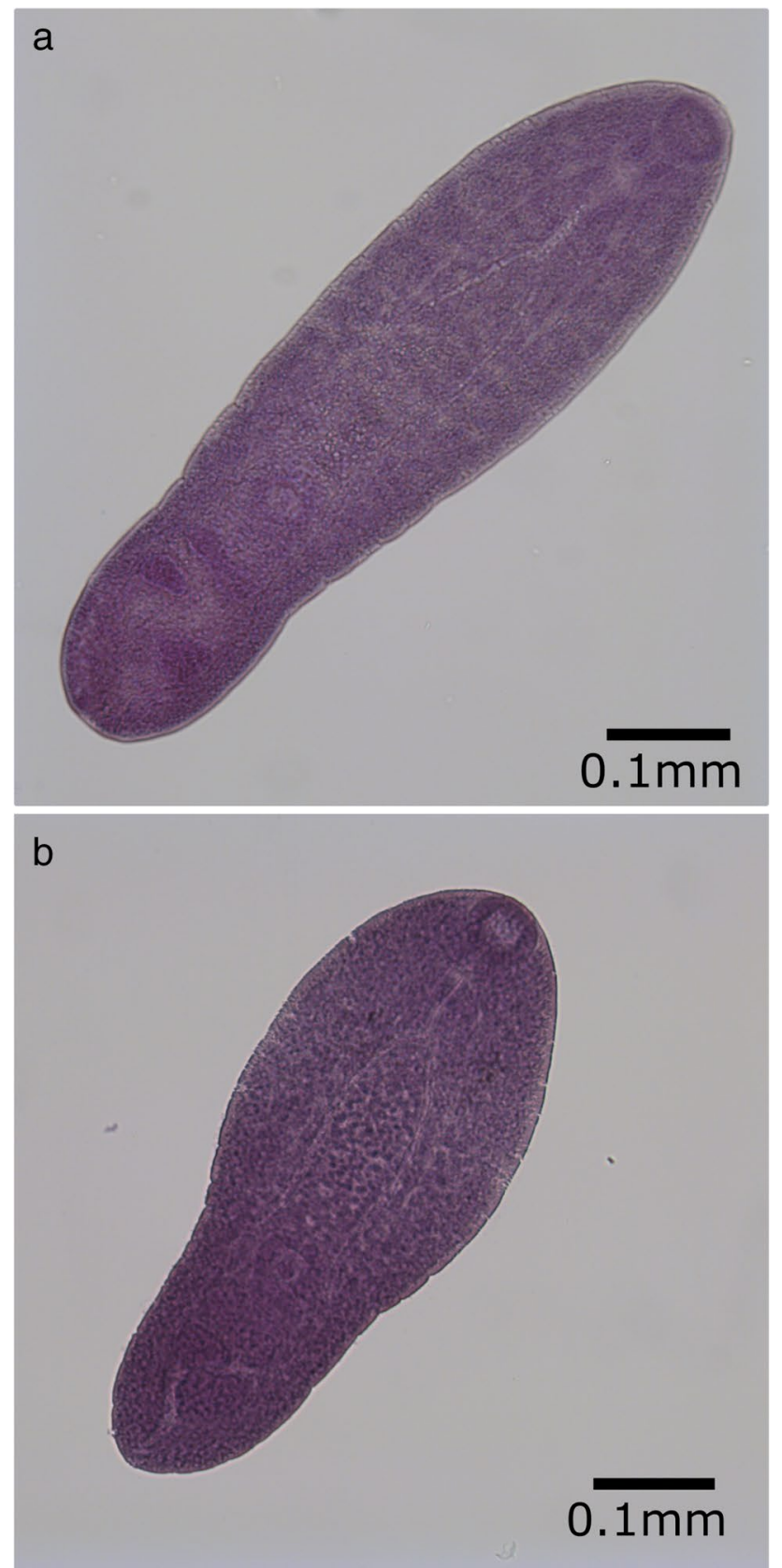

Fig. 3 Excysted Cryptocotyle lingua metacercariae at different degrees of contraction a in whiting from the English Channel, $\mathbf{b}$ in cod from Danish waters

a different position $\left(\mathrm{G}^{9} \rightarrow \mathrm{A}^{59} ; \mathrm{T}^{79} \rightarrow \mathrm{C}^{129} ; \mathrm{G}^{215} \rightarrow \mathrm{C}^{265}\right.$; $\mathrm{G}^{276} \rightarrow \mathrm{A}^{326}$ (Query $\left.\rightarrow \mathrm{KJ} 711866\right)$ ). The last sequence differed from the KJ711866 sequence at two positions $\left(\mathrm{T}^{79} \rightarrow \mathrm{C}^{129} ; \mathrm{C}^{105} \rightarrow \mathrm{T}^{154}\right)$ and showed $99.38 \%$ similarity. All ITS sequences (1708 bp) showed 98 to $100 \%$ similarity with GenBank accession nos. KJ641518 to KJ641524 (C. lingua, Baltic Sea, Denmark). In conclusion, all analysed sequences showed high similarities with $C$. lingua sequences.
Trees based on nucleotide sequences of the coxl gene (281 bp) and the ITS region (1708 bp) showed that all sequences clustered with $C$. lingua with high bootstrap values (Fig. 4) and confirmed BLAST results. In addition, all $C$. lingua sequences, isolated from parasites sampled in the Baltic Sea, Denmark, North America or Europe, form a monophyletic clade.

\section{Discussion}

In this study, parasites inducing black spots on the skin of whiting and cod from northern Europe were identified. Characteristic black melanisation is due to the concentration of melanophores at parasite infection sites (Zander et al. 1984). Several heterophyid genera are responsible for this pathology, e.g. Apophallus (Sándor et al. 2017), Cryptocotyle (Chapman \& Hunter 1954), Haplorchis (Paperna \& Dzikowski 2006) and Stellantchasmus (Chai et al. 2016).

The metacercariae presented in this study belong to Cryptocotyle according to their morphological traits and organ sizes, and their molecular identification. The literature holds only a few accurate descriptions of metacercariae from this genus with measurements of the main characteristic organs. Due to this scarcity, the data of this study were compared with published descriptions of metacercariae (Borges et al. 2015; Goncharov et al. 2017; Rees 1978) and adults (Ransom 1920; Zdzitowiecki et al. 1989). Linton (1915) compared metacercariae from the skin of fish and used adult stages from the intestine of loons as a reference for identification. In most studies, morphological identification of trematode larval stages in fish requires experimental infections to grow the parasite to its adult stage. The adult stage is the only trematode stage in which all the organs are present. However, different stages of maturity (with different degrees of organ development) can be observed in the final host's intestinal tract (McCarthy \& Hassett 1993). In their most suitable hosts, the parasites can grow to a large size and can produce many eggs (Witenberg 1929); in other hosts, the development is not complete, and size can vary (Yoshimura 1965). For example, observing C. lingua in domestic rats, cats and ducks, Stunkard (1929) found that worms that had developed in domestic cats were larger than those recovered from rats, and reproductive organs were not well developed and few eggs were present. He concluded that C. lingua could not mature in domestic ducks. Morphological characteristics thus appear to be host dependent, and each developmental stage needs to be compared with equivalent reference individuals for reliable identification. Here, all the metacercariae from G. morhua and M. merlangus displayed the expected organs of young Cryptocotyle trematodes of marine species. The appearance and organ positions were similar in specimens from both fish species studied (Table 1). 

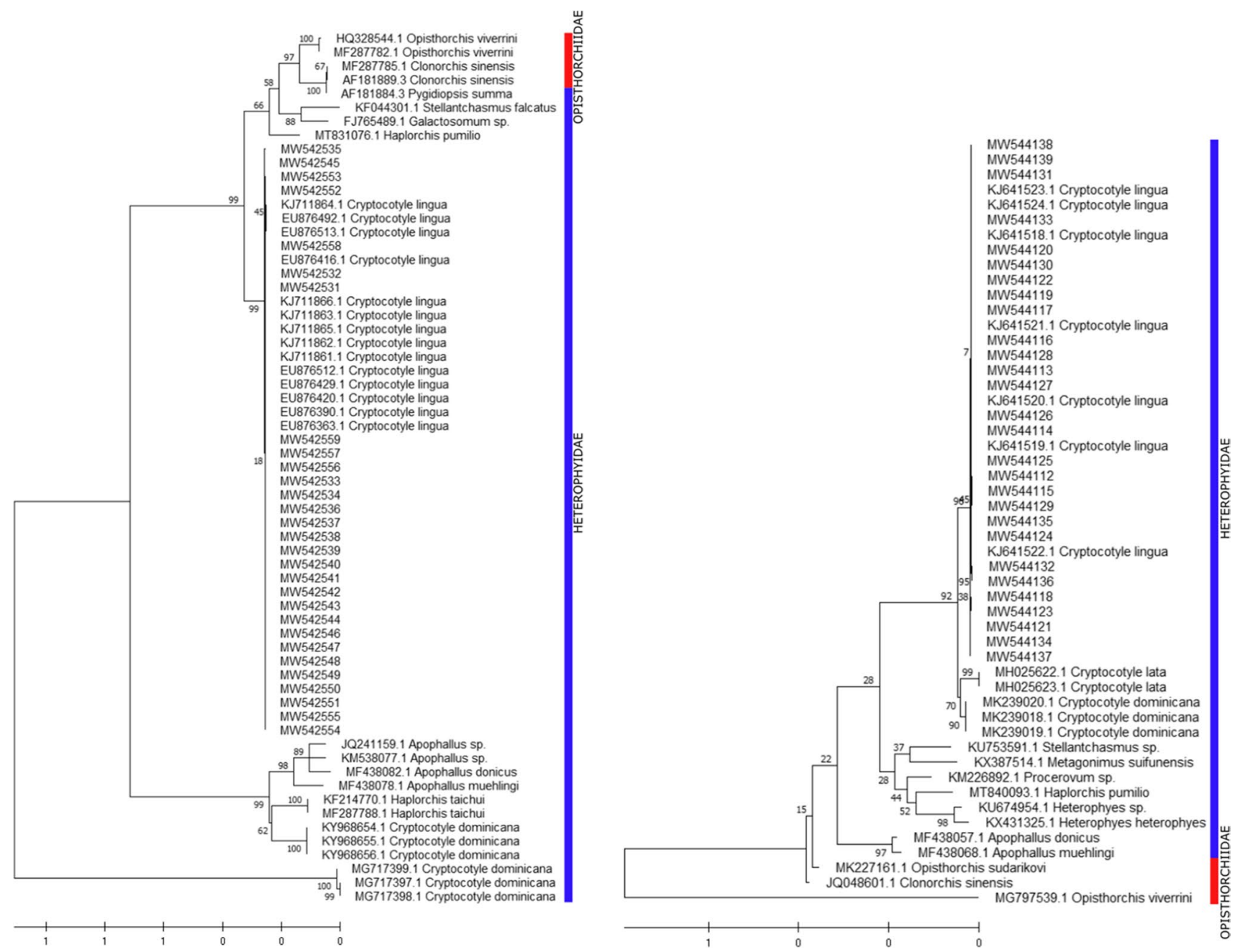

Fig. 4 Phylogenetic trees based on coxl mtDNA (left tree) and ITS rDNA (right tree) sequences using the ML method with 1000 bootstraps

The studied specimens showed the most morphometric similarities with $C$. lingua metacercariae described in Borges et al. (2015) and Rees (1978). Cryptocotyle lingua differs from $C$. concava and $C$. jejuna by its shape and smaller width according to Ransom (1920). However, $C$. lingua metacercariae from the present work and former description from Borges et al. (2015) and Rees (1978) had a total length in the same range as metacercariae from $C$. concava described by Goncharov et al. (2017), whereas their width was considerably smaller. Moreover, regarding total length, parasites differed to $C$. concava, $C$. jejuna and $C$. sp. descriptions by Ransom (1920) and Zdzitowiecki et al. (1989). The distance from the oral sucker to the end of the pharynx was bigger than the ones described by Borges et al. (2015) and Goncharov et al. (2017) for $C$. lingua, $C$. concava and $C$. jejuna metacercariae. The metacercariae studied in this work were markedly smaller than the sizes reported for $C$. lingua adult stages. The measurements were close to minimum values for width, oral sucker diameter, distance from oral sucker to intestinal branches and total length. Therefore, the parasites sampled from whiting and cod matched the descriptions and measurements of $C$. lingua adults observed by Linton (1915), Ransom (1920), Stunkard (1929), Witenberg (1929) and Yoshimura (1965) and the descriptions of metacercariae in Borges et al. (2015) and Rees (1978). These observations are consistent with Pearson's conclusions, cited by Williams and Jones (1994), who considered metacercariae as a juvenile resting stage before adulthood, infecting the definitive host in which it reaches sexual maturity.

Experimental infection of final hosts to study the growth and development of intermediate-stage parasites is laborious and requires laboratory animals. Moreover, specific determination of larval stages based on morphological traits remains difficult, subjective and ambiguous due to the lack of reproductive system traits. Molecular identification to confirm the morphological identification of isolates is strongly recommended. Few sequences are available for the Cryptocotyle 
Table 2 Molecular sequences investigated in the present study

\begin{tabular}{|c|c|c|c|}
\hline \multirow[t]{2}{*}{ Species } & \multirow[t]{2}{*}{ Reference } & \multicolumn{2}{|l|}{ GenBank accession } \\
\hline & & $\operatorname{coxl}$ & ITS \\
\hline Apophallus donicus & Sándor et al. (2017) & MF438082 & MF438057 \\
\hline Apophallus muehlingi & Sándor et al. (2017) & MF438078 & MF438068 \\
\hline Apophallus sp. & Ferguson et al. (2012) & JQ241159 & - \\
\hline Cryptocotyle dominicana & Casalins et al. (2020) & MG717397-MG717399; KY968654-KY968656 & MK239018-MK239021 \\
\hline \multirow[t]{3}{*}{ Cryptocotyle lingua } & Borges et al. (2015) & KJ711861-KJ711866 & KJ641518-KJ641524 \\
\hline & Blakeslee et al. (2008) & $\begin{array}{l}\text { EU876512-13; EU876492; EU876363; } \\
\text { EU876390; EU876416; EU876420; EU876429 }\end{array}$ & - \\
\hline & This study & MW542531-MW542559 & MW544112-MW544139 \\
\hline Cryptocotyle lata & Tatonova and Besprozvannykh (2019) & - & МH025622-МH025623 \\
\hline Galactosomum sp. & Leung et al. (2009) & FJ765489 & - \\
\hline Haplorchis pumilio & Lopes et al. (2020) & MT831076 & MT840093 \\
\hline \multirow[t]{2}{*}{ Haplorchis taichui } & Lee et al. (2013) & KF214770 & - \\
\hline & Dao et al. (2017) & MF287788 & - \\
\hline Heterophyes heterophyes & Henedi (2019) & - & KX431325 \\
\hline Heterophyes sp. & Masala et al. (2016) & - & KU674954 \\
\hline Metagonimus suifunensis & Shumenko et al. (2017) & - & KX387514 \\
\hline Procerovum sp. & Arya et al. (2016) & - & KM226892 \\
\hline Pygidiopsis summa & Lee et al. (2004) & AF181884 & - \\
\hline Stellantchasmus falcatus & Chontananarth et al. (2014) & KF044301 & - \\
\hline Stellantchasmus sp. & Wongsawad et al. (2017) & - & KU753591 \\
\hline \multicolumn{4}{|l|}{ Outgroups } \\
\hline \multirow[t]{3}{*}{ Clonorchis sinensis } & Lee and Huh (2004) & AF181889 & - \\
\hline & Dao et al. (2017) & MF287785 & - \\
\hline & Tatonova et al. (2012) & - & JQ048601 \\
\hline \multirow[t]{3}{*}{ Opisthorchis viverrini } & Thaenkham et al. (2011) & HQ328544 & - \\
\hline & Dao et al. (2017) & MF287782 & - \\
\hline & Sanpool et al. (2018) & - & MG797539 \\
\hline Opisthorchis sudarikovi & Suleman et al. (2019) & - & MK227161 \\
\hline
\end{tabular}

genus in databases (Blakeslee et al. 2008; Borges et al. 2015; Casalins et al. 2020; Duflot et al. 2021b; Tatonova \& Besprozvannykh 2019). In this study, ITS and coxl DNA sequences of $C$. lingua from Atlantic cod and whiting were added to the GenBank database. On the coxl gene, no significant similarity was found with the available sequences of the other parasites causing black spot diseases (Apophallus, Haplorchis, Stellantchasmus). Likewise, the percentage of similarity (4 to $96 \%$ ) and of query cover (10 to $70 \%$ ) was lower for other parasites inducing black spot disease than for Cryptocotyle. Phylogenetic trees on the coxl gene and ITS region showed differences for $C$. dominicana and outgroup phylogenetic positions. This result can be attributed to the evolutionary history of these selected regions. For instance, the selected cox 1 region is a short fragment compared with the ITS region sequence. In both trees, phylogenetic comparisons within the Cryptocotyle genus revealed high sequence similarity for both parasite origins with $C$. lingua cercariae and metacercariae sampled in North America and Europe
(Spain and Norway coasts) (Blakeslee et al. 2008) and in the Baltic Sea (Borges et al. 2015), respectively. On the phylogenetic tree based on ITS region sequences, $C$. lingua, $C$. lata and $C$. dominicana were included in a monophyletic group, whereas other Heterophyidae organisms (Stellantchasmus, Paragonimus, Procevorum, Haplorchis and Heterophyes) were gathered in another monophyletic group. However, both these monophyletic groups seemed to share a common ancestor.

In Scandinavian waters, digenetic trematode infections have been reported in Atlantic cod, with $C$. lingua metacercariae being observed in samples from off the coast of Norway (Heuch et al. 2011) and in 11 of the 15 sampling stations in Danish and adjacent waters (Koie 1984). No previous investigations have been carried out on fish from the English Channel geographic area. Thus, the findings of $C$. lingua in $G$. morhua from Danish seas are consistent with previous studies and confirm the presence of $C$. lingua cercariae in L. littorea snails in the Baltic, Celtic and North seas 
(Thieltges et al. 2009) and in some marine samples from England (Rothschild 1942).

In summary, this paper described for the first time the presence of $C$. lingua in the skin and subcutaneous muscle of M. merlangus from the English Channel using morphological and molecular tools and further confirms the presence of C. lingua in G. morhua in Baltic waters (Borges et al. 2015; Koie 1984). The comparison of morphological and molecular methods needs to be developed in parasitological research, especially for trematode parasites, because molecular data lack for many trematode genera and species. The recent development of molecular tools will help the detection and observation of trematodes at different developmental stages. This complementary approach, based on morphological and molecular data, should prove valuable for poorly described and characterised trematodes and for epidemiological studies on the distribution of Cryptocotyle species in different geographical areas, under different environmental conditions and in a wide variety of fish species.

Acknowledgements The authors are indebted to J. P. Jeppesen, Øresund aquarium (Helsingør, Denmark) for supplying cod for our studies. We also thank all the staff of the Laboratory of Aquatic Pathobiology of the University of Copenhagen for technical help in this study and M. Leblond who fished the whiting samples. In addition, we would like to thank G. Karadjian for his help with the phylogenetic analyses. The authors would like to thank D. Pottratz from Anses and C. EngelGautier from Coup de Puce Expansion for English language editing.

Author contribution All authors contributed to the study conception and design. Material preparation, data collection and analysis were performed by Maureen Duflot. The first draft of the manuscript was written by Maureen Duflot and all authors commented on previous versions of the manuscript. All authors read and approved the final manuscript.

Funding This research was funded by French Agency for Food, Environmental and Occupational Health \& Safety; Hauts de France Regional Council; MED VET NET, SMRE doctoral school, Laboratory of Aquatic Pathobiology of the University of Copenhagen.

Data Availability Not applicable.

Code availability Not applicable.

\section{Declarations}

Competing interests The authors declare no competing interests.

Open Access This article is licensed under a Creative Commons Attribution 4.0 International License, which permits use, sharing, adaptation, distribution and reproduction in any medium or format, as long as you give appropriate credit to the original author(s) and the source, provide a link to the Creative Commons licence, and indicate if changes were made. The images or other third party material in this article are included in the article's Creative Commons licence, unless indicated otherwise in a credit line to the material. If material is not included in the article's Creative Commons licence and your intended use is not permitted by statutory regulation or exceeds the permitted use, you will need to obtain permission directly from the copyright holder. To view a copy of this licence, visit http://creativecommons.org/licenses/by/4.0/.

\section{References}

Aalvik IM, Moland E, Olsen EM, Stenseth NC (2015) Spatial ecology of coastal Atlantic cod Gadus morhua associated with parasite load [Article]. J Fish Biol 87(2):449-464. https://doi.org/10.1111/ jfb. 12731

Altschul SF, Madden TL, Schäffer AA, Zhang J, Zhang Z, Miller W, Lipman DJ (1997) Gapped BLAST and PSI-BLAST: a new generation of protein database search programs. Nucleic Acids Res 25(17):3389-3402. https://doi.org/10.1093/nar/25.17.3389

Arya LK, Rathinam SR, Lalitha P, Kim UR, Ghatani S, Tandon V (2016) Trematode fluke Procerovum varium as cause of ocular inflammation in children, South India [Article]. Emerg Infect Dis 22(2):192-200. https://doi.org/10.3201/eid2202.150051

Blakeslee AMH, Byers JE, Lesser MP (2008) Solving cryptogenic histories using host and parasite molecular genetics: the resolution of Littorina littorea's North American origin [Article]. Mol Ecol 17(16):3684-3696. https://doi.org/10.1111/j.1365-294X. 2008.03865.x

Borges JN, Skov J, Bahlool QZM, Møller OS, Kania PW, Santos CP, Buchmann K (2015) Viability of Cryptocotyle lingua metacercariae from Atlantic cod (Gadus morhua) after exposure to freezing and heating in the temperature range from $-80{ }^{\circ} \mathrm{C}$ to $100{ }^{\circ} \mathrm{C}$ [Article]. Food Control 50:371-377. https://doi.org/10. 1016/j.foodcont.2014.09.021

Bowles J, Hope M, Tiu WU, Liu X, McManus DP (1993) Nuclear and mitochondrial genetic markers highly conserved between Chinese and Philippine Schistosoma japonicum [Article]. Acta Trop 55(4):217-229. https://doi.org/10.1016/0001-706X(93) 90079-Q

Buchmann K (2007) An introduction to fish parasitological methodsclassical and molecular techniques (Vol. 1) [Book]. Biofolia press

Buchmann K, Bresciani J, Pedersen K, Ariel E, Dalsgaard I, Madsen L (2009) Fish diseases - An introduction [Book]. Biofolia

Casalins LM, Arbetman MP, Viozzi GP, Flores VR (2020) A new species of Cryptocotyle (Digenea: Heterophyidae) infecting kelp gull and a galaxiid fish in Patagonian freshwater environments: morphological and molecular analyses [Article]. J Parasitol 106(2):203-210. https://doi.org/10.1645/18-44

Chai J-Y, Sohn W-M, Na B-K, Jeoung H-G, Sinuon M, Socheat D (2016) Stellantchasmus falcatus (Digenea: Heterophyidae) in Cambodia: discovery of metacercariae in mullets and recovery of adult flukes in an experimental hamster [Article]. Korean J Parasitol 54(4):537-541. https://doi.org/10.3347/kjp.2016.54.4.537

Chapman JA, Hunter GW (1954) Studies on host-parasite reactions. VII. The pigment cells surrounding the metacercarial cysts of Cryptocotyle lingua in the cunner, Tautogolabrus adspersus (Walbaum) [Article]. Trans Am Microsc Soc 73(1):28-36. https://doi. org/10.2307/3224182

Chontananarth T, Wongsawad C, Chomdej S, Krailas D, Chai JY (2014) Molecular phylogeny of trematodes in family Heterophyidae based on mitochondrial cytochrome c oxidase subunit I (mCOI) [Article]. Asian Pac J Trop Med 7(6):446-450. https:// doi.org/10.1016/S1995-7645(14)60072-9

Dao TTH, Nguyen TTG, Gabriël S, Bui KL, Dorny P, Le TH (2017) Updated molecular phylogenetic data for Opisthorchis spp. (Trematoda: Opisthorchioidea) from ducks in Vietnam [Article]. Parasit Vectors 10(1):575. https://doi.org/10.1186/s13071-017-2514-9 
Duflot M, Midelet G, Bourgau O, Buchmann K, Gay M (2021a) Optimisation of tools for the detection and identification of Cryptocotyle metacercariae in fish: digestion method and viability studies [Article]. J Fish Disease, in Press. https://doi.org/10.1111/jfd. 13495

Duflot M, Setbon T, Midelet G, Brauge T, Gay M (2021b) A review of molecular identification tools for the Opisthorchioidea superfamily [Article]. J Microbiol Meth 187:106258. https://doi.org/10. 1016/j.mimet.2021.106258

El-Mayas H, Kearn GC (2009) In vitro excystment of the metacercaria of Cryptocotyle concavum from the common goby Pomatoschistus microps [Article]. J Helminthol 69:285-297. https://doi.org/10. 1017/s0022149x00014851

Ferguson JA, Locke SA, Font WF, Steinauer ML, Marcogliese DJ, Cojocaru CD, Kent ML (2012) Apophallus microsoma n. sp. from chicks Infected with metacercariae from Coho Salmon (Oncorhynchus kisutch) and review of the taxonomy and pathology of the genus Apophallus (Heterophyidae) [Article]. J Parasitol 98(6):1122-1132. https://doi.org/10.1645/ge-3044.1

Gonchar A (2020) Genetic diversity in monoxenous and trixenous digeneans sharing one molluscan host species. ПАРАЗИТОЛОГИЯ 54(6):491-503. https://doi.org/10.31857/ s1234567806060036

Goncharov SL, Soroka NM, Pryima OB, Dubovyi AI (2017) Distribution of trematodes Cryptocotyle (Trematoda, Heterophyidae) in fish of the family Gobiidae in estuary waters and the Black Sea in Southern Ukraine. Vestnik Zoologii 51(5):393-400. https://doi. org/10.1515/vzoo-2017-0046

Hall TA (1999) BioEdit: a user-friendly biological sequence alignment editor and analysis program for Windows 95/98/NT [Article]. Nucleic Acids Symp Ser 41:95-98

Henedi A (2019) First molecular identification of adult Heterophyes heterophyes and Heterophyes dispar (digenea: Heterophyidae) from kuwaiti stray cats using ITS2 sequence [Article]. Int J App Natural Sci (IJANS) 8(4):9-20

Heuch PA, Jansen PA, Hansen H, Sterud E, MacKenzie K, Haugen P, Hemmingsen W (2011) Parasite faunas of farmed cod and adjacent wild cod populations in Norway a comparison [Article]. Aquacul Environ Interact 2(1):1-13. http://www.jstor.org/stable/ 24864040

Jukes T, Cantor C (1969) Evolution of protein molecules. Academic Press, New York, NY, pp 21-132

Koie M (1984) Digenetic trematodes from Gadus Morhua L. (Osteichtyes, Gadidae) from danish and adjacent waters, with special reference to their life-histories [Article]. Ophelia 23(2):195-222

Kristoffersen R (1991) Occurrence of the digenean Cryptocotyle lingua in farmed Arctic charr Salvelinus alpinus and periwinkles Littorina littorea sampled close to charr farms in northern Norway [Article]. Dis Aquat Organ 12(1):59-65. https://www.scopus. $\mathrm{com} /$ inward/record.uri?eid=2-s2.0-0026380218\&partnerID=40\& md5 $=$ cdc74e66a777f67e853cc8072610ada 1

Kumar S, Stecher G, Li M, Knyaz C, Tamura, K (2018) MEGA X: Molecular Evolutionary Genetics Analysis across computing platforms [Article]. Mol Biol Evol 35(6):1547-1549. https://doi.org/ 10.1093/molbev/msy096

Landis SH, Kalbe M, Reusch TBH, Roth O (2012) Consistent pattern of local adaptation during an experimental heat wave in a pipefishtrematode host-parasite system [Article]. PLoS ONE 7(1):e30658. https://doi.org/10.1371/journal.pone.0030658

Lee D, Choe S, Park H, Jeon HK, Chai JY, Sohn WM, Yong TS, Min DY, Rim HJ, Eom KS (2013) Complete mitochondrial genome of Haplorchis taichui and comparative analysis with other trematodes [Article]. Korean J Parasitol 51(6):719-726. https://doi.org/ 10.3347/kjp.2013.51.6.719
Lee S-U, Huh S (2004) Variation of nuclear and mitochondrial DNAs in Korean and Chinese isolates of Clonorchis sinensis [Article]. Korean J Parasitol 42(3):145-148. https://doi.org/10.3347/kjp. 2004.42.3.145

Lee SU, Huh S, Sohn WM, Chai JY (2004) Sequence comparisons of 28S ribosomal DNA and mitochondrial cytochrome c oxidase subunit I of Metagonimus yokogawai, M. takahashii and M. miyatai [Article]. Korean J Parasitol 42(3):129-135. https://doi.org/10. 3347/kjp.2004.42.3.129

Leung TLF, Donald KM, Keeney DB, Koehler AV, Peoples RC, Poulin R (2009) Trematode parasites of Otago Harbour (New Zealand) soft-sediment intertidal ecosystems: life cycles, ecological roles and DNA barcodes [Article]. NZ J Mar Freshwat Res 43(4):857865. https://doi.org/10.1080/00288330909510044

Linton E (1915) Tocotrema lingua (Creplin) The adult sage of a skin parasite of the cunner and other fishes of the woods hole region [Article]. J Parasitol 1(3):107-158

Lopes AS, Pulido-Murillo EA, Melo AL, Pinto HA (2020) Haplorchis pumilio (Trematoda: Heterophyidae) as a new fish-borne zoonotic agent transmitted by Melanoides tuberculata (Mollusca: Thiaridae) in Brazil: a morphological and molecular study [Article]. Infect Genet Evol 85:104495. https://doi.org/10.1016/j.meegid. 2020.104495

Masala S, Piras MC, Sanna D, Chai JY, Jung BK, Sohn WM, Garippa G, Merella P (2016) Epidemiological and molecular data on heterophyid trematode metacercariae found in the muscle of grey mullets (Osteichthyes: Mugilidae) from Sardinia (western Mediterranean Sea) [Article]. Parasitol Res 115(9):3409-3417. https:// doi.org/10.1007/s00436-016-5101-7

Mazzi D (2004) Parasites make male pipefish careless [Article]. J Evol Biol 17(3):519-527. https://doi.org/10.1111/j.1420-9101. 2004.00704.x

McCarthy TK, Hassett DJ (1993) Cryptocotyle lingua (Creplin) (Digenea: Heterophyidae) and other parasites of a coastal otter Lutra lutra (L.) [Article]. Irish Natural J 24(7):280-282. http://www. jstor.org/stable/25539838

McQueen A, Mackenzie K, Roberts RJ, Young H (1973) Studies on the skin of plaice (Pleuronectes platessa L.): III. The effect of temperature on the inflammatory response to the metacercariae of Cryptocotyle lingua (Creplin, 1825) (Digenea: Heterophyidae) [Article]. J Fish Biol 5(2):241-247. https://doi.org/10.1111/j. 1095-8649.1973.tb04453.x

Paperna I, Dzikowski R (2006) Digenea (Phylum Platyhelminthes). In: Woo PTK (ed) Fish diseases and disorders, 2nd edn, vol 1. CABI International, pp 345-390

Ransom BH (1920) Synopsis of the Hetrophyidae with descriptions of a new genus and five new species [Article]. U.S. NATIONAL MUSEUM 57(2322):527-552

Rea JG, Irwin SWB (1991) Behavioural responses of the cercariae of Cryptocotyle lingua (Digenea: Heterophyidae) to computer-controlled shadow sequences [Article]. Parasitology 103(03). https:// doi.org/10.1017/s0031182000059990

Rees FG (1978) The ultrastructure, development and mode of operation of the ventrogenital complex of Cryptocotyle lingua(Creplin) (Digenea: Heterophyidae) [Article]. Proc Royal Soc London. Ser B Biol Sci 200(1140):245-267. http://www.jstor.org/stable/77390

Rees G (1974) The ultrastructure of the body wall and associated structures of the cercaria of Cryptocotyle lingua (Creplin) (Digenea: Heterophyidae) from Littorina littorea (L.) [Article]. Zeitschrift für Parasitenkunde 44(3):239-265. https://doi.org/10.1007/BF003 28765

Rothschild M (1942) A seven-year-old infection of Cryptocotyle lingua Creplin in the winkle Littorina littorea L. [Article]. The Journal of Parasitology 28(4):350-350. https://doi.org/10.2307/3272976 
Sándor D, Molnár K, Gibson DI, Székely C, Majoros G, Cech G (2017) An investigation of the host-specificity of metacercariae of species of Apophallus (Digenea: Heterophyidae) in freshwater fishes using morphological, experimental and molecular methods [Article]. Parasitol Res 116(11):3065-3076. https://doi.org/10.1007/ s00436-017-5617-5

Sanpool O, Aung WPP, Rodpai R, Maleewong W, Intapan PM (2018) Human liver fluke Opisthorchis viverrini (Trematoda, Opisthorchiidae) in Central Myanmar: new records of adults and metacercariae identified by morphology and molecular analysis [Article]. Acta Trop 185:149-155. https://doi.org/10.1016/j.actat ropica.2018.05.009

Sekhar CS (1970) Infection of the dinner, Tautogolabrus adspersus (Walbaum), with Metacercariae of Cryptocotyle lingua (Creplin, 1825) [Article]. J Helminthol 44(2):189-198. https://doi.org/10. 1017/S0022149X00021738

Shumenko PG, Tatonova YV, Besprozvannykh VV (2017) Metagonimus suifunensis sp. n. (Trematoda: Heterophyidae) from the Russian Southern Far East: Morphology, life cycle, and molecular data [Article]. Parasitol Int 66(1):982-991. https://doi.org/10. 1016/j.parint.2016.11.002

Sindermann CJ, Farrin AE (1962) Ecological studies of Cryptocotyle lingua (Trematoda: heterophyidae) whose larvae cause "pigment spots" of marine fish [Article]. Ecol Soc Am (ESA) 43(1):69-75

Smyth JD (1994) Introduction to animal parasitology [Book]

Stunkard HW (1929) The life history of Cryptocotyle lingua (Creplin) with notes on the physiology of the metacercariae [Article]. $\mathrm{J}$ Morphol Physiol 50(1):143-191

Stunkard HW (1942) Studies on pathology and resistance in terns and dogs infected with the heterophyid trematode, Cryptocotyle lingua [Article]. Transact Amer Microscop Soc 61(3):236-253. http:// www.jstor.com/stable/3222594

Suleman, Ma J, Khan MS, Sun MM, Muhammad N, He JJ, Zhu XQ (2019) Mitochondrial and nuclear ribosomal DNA dataset suggests that Hepatiarius sudarikovi Feizullaev, 1961 is a member of the genus Opisthorchis Blanchard, 1895 (Digenea: Opisthorchiidae) [Article]. Parasitol Res 118(3):807-815. https://doi.org/10. 1007/s00436-019-06227-8

Tamura K, Nei M (1993) Estimation of the number of nucleotide substitutions in the control region of mitochondrial DNA in humans and chimpanzees. Mol Biol Evol. https://doi.org/10.1093/oxfor djournals.molbev.a040023

Tatonova YV, Besprozvannykh VV (2019) Description of a new species, Cryptocotyle lata sp. nov., and discussion of the phylogenetic relationships in Opisthorchioidea [Article]. Parasitology International 72:101939. https://doi.org/10.1016/j.parint.2019.101939

Tatonova YV, Chelomina GN, Besprosvannykh VV (2012) Genetic diversity of nuclear ITS1-5.8S-ITS2 rDNA sequence in Clonorchis sinensis Cobbold, 1875 (Trematoda: Opisthorchidae) from the Russian Far East [Article]. Parasitol Int 61(4):664-674. https://doi.org/10.1016/j.parint.2012.07.005
Thaenkham U, Nuamtanong S, Vonghachack Y, Yoonuan T, Sanguankiat S, Dekumyoy P, Prommasack B, Kobayashi J, Waikagul J (2011) Discovery of Opisthorchis lobatus (Trematoda: Opisthorchiidae): a new record of small liver flukes in the greater mekong sub-region [Article]. J Parasitol 97(6):1152-1158. https:// doi.org/10.1645/GE-2764.1

Thieltges DW, de Montaudouin X, Fredensborg B, Jensen KT, Koprivnikar J, Poulin R (2008) Production of marine trematode cercariae a potentially overlooked path of energy flow in benthic systems [Article]. Mar Ecol Prog Ser 372:147-155. http://www. jstor.org/stable/24872726

Thieltges DW, Ferguson MAD, Jones CS, Noble LR, Poulin R (2009) Biogeographical patterns of marine larval trematode parasites in two intermediate snail hosts in Europe [Article]. J Biogeograph 36(8):1493-1501. http://www.jstor.org/stable/40305913

Thuy DT, Kania P, Buchmann K (2010) Infection status of zoonotic trematode metacercariae in Sutchi catfish (Pangasianodon hypophthalmus) in Vietnam: Associations with season, management and host age [Article]. Aquaculture 302(1-2):19-25. https:// doi.org/10.1016/j.aquaculture.2010.02.002

Williams H, Jones A (1994) Parasitic worms of fish [Book]. Taylor \& Francis

Witenberg G (1929) Studies on the trematode-family heterophyidae [Article]. Ann Trop Med Parasitol 23(2):131-239. https://doi.org/ 10.1080/00034983.1929.11684600

Wongsawad C, Nantarat N, Wongsawad P (2017) Phylogenetic analysis reveals cryptic species diversity within minute intestinal fluke, Stellantchasmus falcatus Onji and Nishio, 1916 (Trematoda, Heterophyidae) [Article]. Asian Pac J Trop Med 10(2):165-170. https://doi.org/10.1016/j.apjtm.2017.01.016

Yoshimura K (1965) On the tremtode species Phocitrema fusiforme Goto and Ozaki, 1930 and Cryptocotyle lingua (Creplin, 1825) [Article]. Japanese J Vet Res 13(2):15-18. https://doi.org/10. 14943/jjvr.13.2.15

Zander CD, Kollra HG, Antholz B, Meyer W, Westphal D (1984) Small-sized euryhaline fish as intermediate hosts of the digenetic trematode Cryptocotyle concavum [Article]. Helgoländer Meeresuntersuchungen 37(1-4):433-443. https://doi.org/10.1007/ BF01989322

Zdzitowiecki K, Niewiadomska K, Drozdz J (1989) Trematodes of birds and mammals in the environs of $h$. arctowski station south shetlands antarctic [Article]. Acta Parasit Polon 34(3):247258. https://eurekamag.com/research/007/968/007968169.php

Publisher's note Springer Nature remains neutral with regard to jurisdictional claims in published maps and institutional affiliations. 